\title{
Thormation
}

Nordic Journal of Art and Research

ISSN: 1893-2479

www.artandresearch.info

\section{Emancipatory Theatre and Performative Didactics}

\author{
Venke Aure ${ }^{1}$, Karin B. Bjerkestrand ${ }^{2}$ and Anna Songe Møller ${ }^{3}$ \\ Oslo and Akershus University College of Applied Sciences/University of Stavanger
}

\begin{abstract}
This article is based on several years of empirical observation, gathered from theatre practice, in which Karin B. Bjerkestrand and Anna Songe-Møller developed what is known as "Solidarity Forum Theatre" (SFT), a form of applied drama. This theatre form is based primarily on the Brazilian, Augusto Boal's, Theatre of the Oppressed (Boal, 2006). Bjerkestrand and Songe-Møller used and further developed Boal's theatre principle in a collaboration with various immigrant groups and drama-/theatre students. The intention has been to use the liberating potential into which this form of theatre invites us. In this article, Bjerkestrand and Songe-Møller present the theoretical groundwork, the underlying principles, and examples of SFT in action. One of the participants' stories in particular have been used to concretize the liberating aspect that arose in the theatre experiences. In relation to this Solidarity Forum Theatre practice, science theorist and art educator Venke Aure presents epistemological and didactic reflections.
\end{abstract}

Keywords: Emancipatory theatre, performative didactics, action based research, personal narratives, epistemology

A story told by Aisha, one of the participants in the Solidarity Forum Theatre:

Early one morning, I walked in a hurry to reach the lesson at the University in my homeland. To be able to study, I had to earn money and work late at evening and nights. I was tired, but felt very happy to be a student at the faculty of medicine. My country was lacking doctors. I wanted to become a good doctor in a country that needed well-educated healthcare. It was a rainy day and the wind was blowing. I had an umbrella in one hand and my books in the other, held very close to my body in order not to lose them. Suddenly, I was stopped by two persons from the religious police who made me aware that some

\footnotetext{
${ }^{1}$ Department of Art, Design and Drama, Oslo and Akershus University College of Applied Sciences, PB 4, St. Olavs Plass, N-0130. E-mail: Venke.Aure@hioa.no

${ }^{2}$ Department of Art, Design and Drama, Oslo and Akershus University College of Applied Sciences, PB 4, St. Olavs Plass, N-0130. E-mail: karin-brunvathne.bjerkestrand @hioa.no

${ }^{3}$ University of Stavanger, 4036 Stavanger. E-mailt: anna.songe-moller@uis.no
} 
of my hair had fallen out of the hijab. I was brought to the office of the headmaster at the University, where they reminded me that it is strictly forbidden for women, under any circumstances, to show their hair in public places. I asked for forgiveness and said I did not intend to break the law. I had to take care of the books and the umbrella, and that's why I was unable to control my long, thick, curly hair. I was granted no forgiveness for this, but was told that I was no longer wanted as a student. I had to leave the University forever. My life - dream was shattered.

I went to Norway, as a refugee, got asylum, married, and had children. After some years, my story was staged and discussed through SFT.

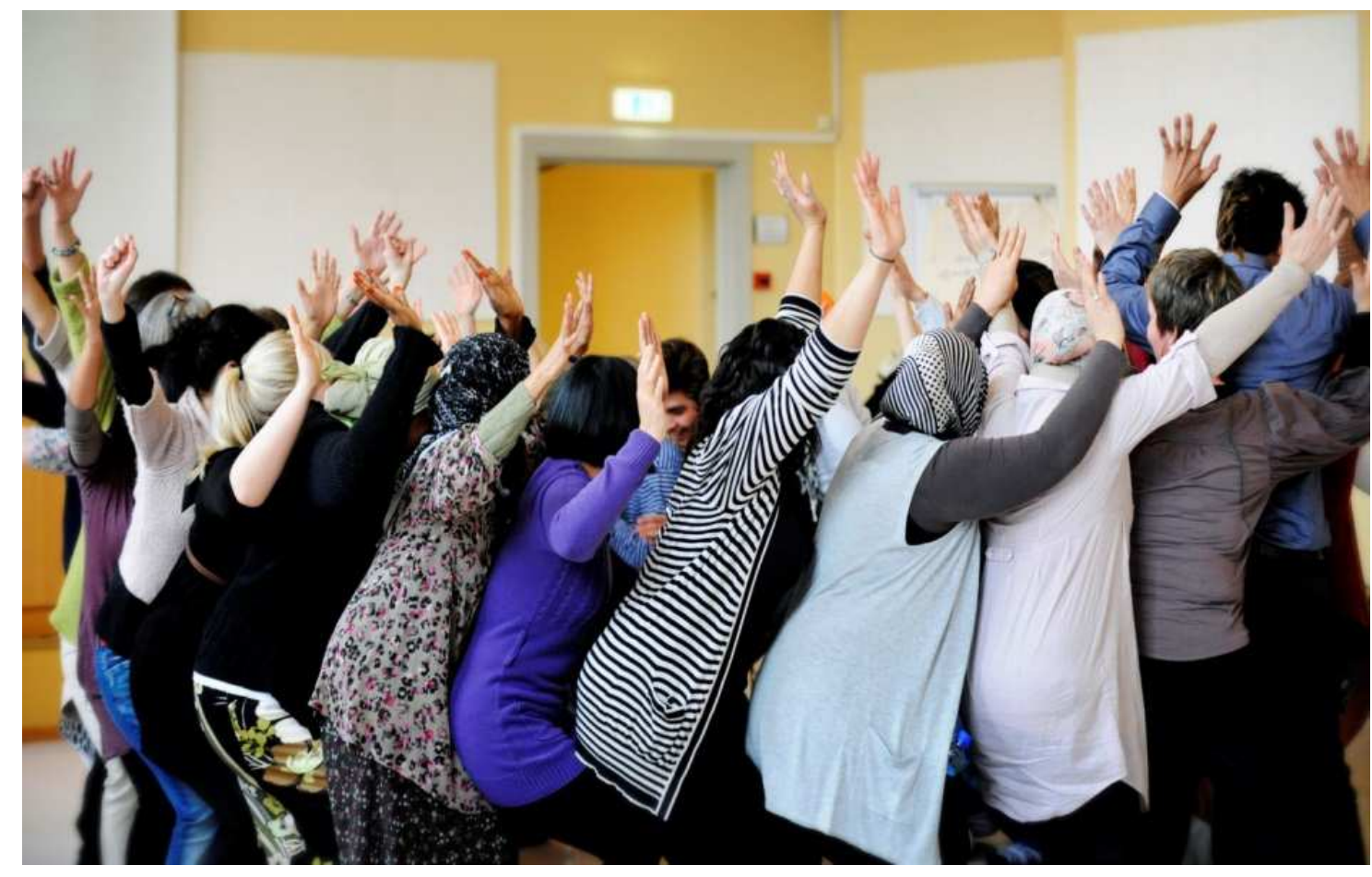

Photo: Elin Eike Worren

Three years later:

I have completed my primary studies in Norway and I am now completing high school. I have got good grades, which enables me to study at a University. It is not possible to study medicine in the town where I live with my family, but I'm looking forward to becoming an engineering student.

This article is based on several years of empirical observation, gathered from theatre practice, in which Karin B. Bjerkestrand and Anna Songe-Møller developed what is known as "Solidarity Forum Theatre" (SFT), a form of applied drama. Bjerkestrand and Songe-Møller have used and further developed Augusto Boal's theatre principles in collaboration with various immigrant groups and drama-/theatre students. The intention has been to use the liberating potential into which this form of theatre invites us. The article highlights the way we believe that participation in Emancipatory Theatre influenced Aisha's choices, which ultimately led to her decision to pursue engineering studies. 
In this study, Bjerkestrand and Songe-Møller present the theoretical groundwork, the underlying principles, and examples of SFT in action. In relation to this, science theorist and art educator Venke Aure presents epistemological and didactic reflections. In the course of the last two years, she has participated in parts of SFT from a more participatory observation perspective. While empirical proximity to the project has been primarily critical, Aure's point of departure has been to frame the project in a historical and meta-theoretical perspective. In addition to borrowing from, among other things, Willmar Sauter's emphasis on theatre as a "a communicative event" (Sauter, 2000) and Erika Fischer-Lichte's emphasis on "the transformative power of performance" (FischerLichte, 2008), looking at SFT from the perspective of science and didactic theory has led to the characterization of SFT as performative didactics (Aure, 2011). The analysis is inspired by Norman Denzin's clear highlighting of performance theory's political conditions of feasibility (Denzin, 2003). The collaboration between the three authors represents an inter-disciplinary approach, which we believe can contribute to an understanding of SFT from the perspective of broadened theoretical frameworks. For the most part, this perspective can contribute to repairing the concepts and further developing the knowledge of theatre-based experiences and research processes. We wanted to clarify our roles, expressively, by alternately writing from both a group "we" and an individual "I" perspective, as related to the different responsibilities in the project.

\section{"I" (Venke): Background and Epistemological Frameworks}

Throughout history, theatre, as a social phenomenon has been closely related to society's production of different competing epistemologies, containing different views on knowledge, values, and theatre. In Greek antiquity, the theatre represented a site for the masses to learn the cultic religious rituals (Braanaas, 2008, p.16). Comedies containing clearly political satire were a parallel tradition of that time. Arne Engelstad argues that such satire in, for example, Aristophanes' comedies, was so strong that today, they would lead to defamation proceedings (Engelstad, 2001, p.112). Simply put, one could argue that these two traditions form what has been the theater's main function through the centuries, to instruct and to entertain (Engelstad, 2001, p.116). Despite the differing intentions of these theater forms, a certain one-way communication is a common characteristic - the actors speak and perform, the members of the audience listen and watch. The medieval theatre was also related to religion, and had a clearly uttered didactic intention to elucidate the morals in the Bible (Braanaas, 2008:18). During the Renaissance, the humanistic aspect was supported, as was individual reasoning and independence; nonetheless, the theatre's chosen content was still strongly connected to religious themes. These descriptions make visible theatre, as a part of society's accepted conventions, to a strong degree related to religion. At the same time, during these long-lasting historical epochs, a parallel story could be told, and here theatre came to be condemned and expelled if the chosen thematic was distant from the religious didactic legitimating sphere (Braanaas, 2008, p.19). Bishop 
Eric Pontoppidan's pietistic view on theatre, as a devilish sin, is an example of the hostile attitude from the seventeenth century.

These different positions regarding the theatres' role have one mutual aspect, namely the didactic intentions as the foundation for the activities (Braanaas, 2008, p.26). Here, it can be added that the theatre practices were largely based on what I will call a static didactics to maintain established knowledge and conventions. From a broader perspective, this tradition can be understood as a political attempt to retain social norms and power. To follow this perspective, I will claim that theatre, and art museums as well, developed as a part of the Anglo-American and Western societies endeavor to build national states in the eighteenth century. These institutions were used to show what images and contents were considered part of a country's cultural heritage and identity. For a story or an art collection, the audience was presented with a given meaning about which there should be no doubt. The meaning was given in what was showed, in the art itself. Theatre theoretician Willmar Sauter described this position, as the composite work of art was built upon positivist theory, which believed in the possibility of reconstructing facts, theatre as a system of signs (Sauter, 2000, p.12). With art historian Carol Duncan's concepts, these places for display can be characterized as ritual and structured spaces (Duncan, 1995). These descriptions could, I argue, display an essentialistic epistemology characterized by previously given elements connected to the inner logic and underlying systems of meaning in the sphere of the theatre or the visual art itself. Sauter further emphasizes that an overview of European theatre studies in the twentieth century shows a transition in the conceptualizing of theatre, as a shift from the idea of theatre as a work of stage art, or simply a piece of art toward an understanding of theatre as a communicative event (Sauter, 2000, p.20). Theatre, as a work of art, is described as something that is produced, distributed, consumed, etc., and while in strict opposition, theatre, as event, includes "both the presentation of actions and the reactions of the spectators, who are present at the very moment of the creation" (Sauter, 2000, p.11).

Bertolt Brecht can be understood as a part of this paradigmatic shift; he symptomatically called his theater anti-Aristotelian to stress his endeavor to sensitize the viewers by getting them to be critical of the conditions for action in the play and see alternative stories. Musicologist Tony Valberg understands Brecht's plays on this basis, and describes the plays as grounded in a rebellious strategy with, among other things, the intention to create unrest in respect to dramatic conventions between the auditorium and the stage (Valberg, 2013, p.60). After the staging of Brecht's plays, there is the additional intention to transform the audience's status from that of consumer to producer, ostensibly by the distribution of questions, to be answered and discussed, concerning the performance's content. These changes represent, more generally, that art was no longer seen as a supplier of historical and static cultural values, but on the contrary, plays were seen as sites for discussion of crucial topics in society. Regarding the essentialistic epistemology, this orientation can be understood as a destabilized strategy, which also included critical points of view regarding the theatre institution itself. 
The shift from theatre as a work of art to theatre as an event is thus part of a broader epistemological change. In the field of literature, the change was clearer in the genres that invited the reader in as co-author. In the same way that reading to decode a text is replaced with participants listening, theatre theoretician Erika Fischer-Lichte also considers the popularity of the narrating tradition as part of this trend, "as it came to life through the voices and the physically present readers and seeped into the imaginations of the physically present listeners by appealing to their various senses" (Fischer-Lichte, 2008, p.20). In the field of music, composer and avant-garde artist John Cage's challenge to the conventional allocation of roles between the musician and the audience is prominent in his music-of-chance ideology, in which the element of music is partly left to experimental chance. For the most part, we are referred to his conceptual composition "4'33" from 1952, in which the title indicates the duration of the track that was performed without a single note being played. A more blatant break with the audience's expectation of the distant pleasure of off-thepeg compositions would be hard to find.

Within the field of visual arts, the work internal, autonomous art was replaced with perspectives which emphasized the relationships between the content, the situation-contingency, and the work's capacity to interact with the observer. This change is described through the relational concept, established in literature, which addresses the invitation in the contemporary arts to interaction between the observer and the work of art. ${ }^{4}$ The following quote from literary theorists Kuisma Korhonen and Pajari Räsänen supports the idea that this change was contingent on different and broad areas.
We may argue that modern Western thought has been marked by a shift from an essentialist and fetishist approach, concentrating on objects, entities, and their identities, to a non- essentialist approach, where the emphasis is placed on relations and encounters rather than on the entities as self-sufficient objects or subjects. We can see this shift taking place, little by little, in various fields, from philosophy to physics, from epistemology to ethics.
(Korhonen \& Räsänen, 2010, p.9)

It is in the light of these comprehensive epistemological turns that the Solidarity Forum Theatre (SFT) must be understood with the theatre form's emphasis on the procedural, participatory, and liberational strategies. This will be specified in the following theoretical and empirical presentation of SFT.

\section{We" (Anna \& Karin): The Solidarity Forum Theatre}

The Brazilian, Augusto Boal, is the founder of Theatre of the Oppressed (TO), named in honor to Paulo Freire's Pedagogy of the Oppressed (Freire, 2003). Boal's life experiences inspired him to develop various theatrical forms and methods, such as Forum Theatre, Invisible Theatre, and Image Theatre. The goal in TO is to stop oppression. The Latin word forum means marketplace, and in Forum Theatre, we highlight oppressive situations and problems and then open for debate through

\footnotetext{
${ }^{4}$ The concept of relational aesthetic is ascribed to the art theorist Nicolas Bourriaud, who in 1998 published Relational Aesthetics.
} 
theatrical fiction (Boal, 2006). Boal was a theatre director, dramatist, theorist, writer, and teacher; to illustrate his reflection around theatre work, he drew the Tree of the Theatre of the Oppressed.

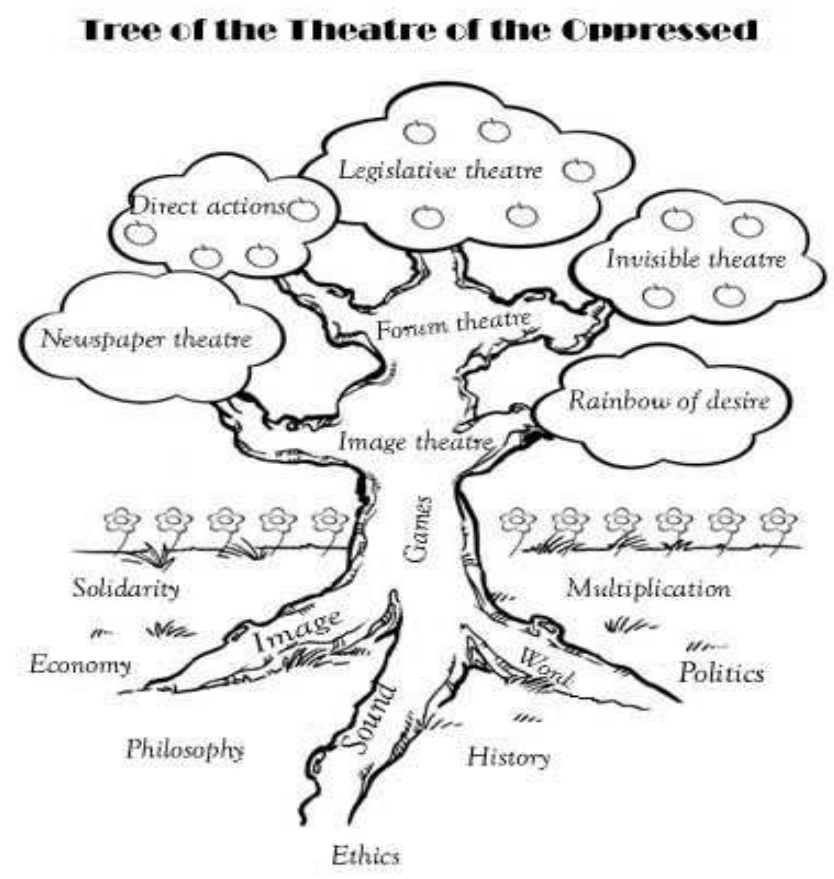

Figure from Boal, 2006:3.

This tree shows the strict relationship between the different techniques and theatre forms in TO; it is based on the foundations of economy, philosophy, ethics, history and politics, which are also the nutrients of the tree: "The objective of the whole tree is to bring forth fruits, seeds and flowers: this is our desired goal. In order that the Theatre of the Oppressed may seek not only to understand reality, but to transform it to our liking." (Boal, 2006, p.7). Boal's mandatory requirements of TO are of both an ethical and an aesthetic character: to provide assistance to the oppressed own liberation, and to give them this help in the form of tools from the theatre language and aesthetics. The Theatre of the Oppressed should function as a weapon against oppression in all its minor and major manifestations.

In Forum Theatre, the participants enact problems and discuss them through theatrical fiction. The actors present different scenes that demonstrate oppression. These scenes are replayed with spontaneous interventions by spectators who enter the stage, replace the protagonist (main role), change the dramatic action through improvisation, and try out possible solutions and changes to stop the oppression. Forum Theatre breaks the distinction between public and the stage to give everyone equal roles and opportunities. The spectator then becomes what Boal called 'spect-actor', which means an active spectator who takes part in the action on stage (Boal, 2002, p.xxvi). Augusto Boal claimed that the participants in Forum Theatre should be one homogenous group, so they could have a common identification with the theme of the oppression being explored. Here are some examples of 
what Boal saw as homogenous groups: "schools, factories, daycentres, community centres, tenants' groups, homeless people, disabled people, people in ethnic minorities, and so on - anywhere where there is a community which shares an oppression" (Boal, 2002, p.xxiv). In our work, we further developed Forum Theatre into Solidarity Forum Theatre by facilitating the meeting of two different homogenous groups, namely immigrants and drama students. The term homogenous can of course be questioned - immigrants are people from all continents, languages, cultures, and backgrounds. In this context, we name them as one "homogenous group", based on what they have in common; they were not born in Norway, and they recently came to Norway as adult immigrants. They are refugees, asylum seekers, and immigrants joining their family in Norway. They come from countries in Asia, Africa, Eastern Europe, and a few from South and Central America. Many of them received little education before coming to Norway, and some can be considered illiterate. There are both youths and adults, aged nineteen and upwards, some of whom have a goal to pass the Norwegian compulsory education examination in order to be accepted at schools for higher secondary education. The other group, the ethnic Norwegians, have in common that they were born in Norway and they are drama students. They are future teachers in schools, and community cultural workers for children, youth, and adults. In SFT, these two groups explore challenges that arise in the meeting of different cultures, religions, values, and attitudes in a multicultural society. SFT requires solidarity and the willingness to listen to and empathize with people who have different experiences with oppression. We have taken the concept of solidarity to mean cohesion, loyalty, mutual responsibility, and respect (Berulfsen \& Gundersen, 1993, p.330).

The process of SFT consists of seven phases, with a progression where the phases logically follow each other:

\begin{tabular}{|l|l|}
\hline Phase 1: Contact and Contract. & $\begin{array}{l}\text { The project leaders and the teachers at the } \\
\text { Learning Centers for Immigrants discuss time, } \\
\text { place, and duration of the work. }\end{array}$ \\
\hline $\begin{array}{l}\text { Phase 2: Knowledge About Solidarity Forum } \\
\text { Theatre. }\end{array}$ & Drama students are given knowledge about SFT. \\
\hline Phase 3: Mutual Knowledge About Each Group. & $\begin{array}{l}\text { Drama students receive knowledge about the } \\
\text { general situation of the immigrants. Immigrants } \\
\text { acquire knowledge about "Communication and } \\
\text { Cultural Understanding" through their training } \\
\text { course. }\end{array}$ \\
\hline
\end{tabular}




\begin{tabular}{|c|c|}
\hline $\begin{array}{l}\text { Phase 4: The First Encounter Between } \\
\text { Immigrants and Drama Students. }\end{array}$ & $\begin{array}{l}\text { This phase involves introductory training, from } \\
\text { Augusto Boal's work, with games, exercises, and } \\
\text { Image Theatre. }\end{array}$ \\
\hline $\begin{array}{l}\text { Phase 5: Experienced Life Stories Become } \\
\text { Theatre. }\end{array}$ & $\begin{array}{l}\text { Drama students and immigrants share their } \\
\text { experiences of oppression with each other. They } \\
\text { choose cases to be performed on stage. This may } \\
\text { include experiences from shops, schools, asylum, } \\
\text { restaurants, buses, law offices, or jobs where } \\
\text { oppression is part of the experience. The forum } \\
\text { play is a presentation of reality as we do not wish } \\
\text { it to be, an anti-model, in which oppression is } \\
\text { evident. The forum play ends when the } \\
\text { oppression is at its worst or most tragic. Both } \\
\text { drama students and immigrants are actors. }\end{array}$ \\
\hline Phase 6: From Spectator to Spect-Actor. & $\begin{array}{l}\text { Solidarity Forum Theatre is performed in a } \\
\text { canteen, a library, or a hall for larger audiences at } \\
\text { the Learning Center for Immigrants. The number } \\
\text { of spectators can vary from two hundred to three } \\
\text { hundred. The spectators are invited to take the } \\
\text { role of the oppressed on stage and explore other } \\
\text { forms of reacting to stop the oppressive } \\
\text { situations. The spectator then becomes a spect- } \\
\text { actor on stage. The Solidarity Forum Theatre is } \\
\text { led by a joker, an anti-authoritarian play leader. } \\
\text { The joker warms up the spectators with games } \\
\text { and exercises. }\end{array}$ \\
\hline $\begin{array}{l}\text { Phase 7: Experience, Acknowledgement, and } \\
\text { Reflection. }\end{array}$ & $\begin{array}{l}\text { The participants: drama students, immigrants, } \\
\text { and instructors share their experiences from the } \\
\text { SFT-event. They are seated in a circle, and one } \\
\text { after one they tell what was most important to } \\
\text { them in the work with SFT. }\end{array}$ \\
\hline
\end{tabular}

(Songe-Møller, A. S. \& Bjerkestrand, K. B., 2012, p.2) 
A SFT performance usually consists of four to five forum plays, which last around five minutes each. Even though most of the immigrant students have no experience acting, they accepted to participate as actors, together with the drama students, in the forum plays. The forum plays express life stories with situations and events that the participants have experienced as oppressive. By staging their stories, the immigrants and the drama students get the opportunity to see themselves from an outside perspective, through fiction. An example is Aisha's story about when she was expelled from the University in her home country. In the article we have chosen to focus upon Aisha`s participation in SFT, because we find her experiences illustrating to illuminate the emancipatory potential of Solidarity Forum Theatre. Her process from phase four to seven reveals her development and self-reflection, which may clarify and confirm the structure and progression of the phases in SFT.

\section{Observations and findings from SFT processes}

This article is based on twenty-two SFT performances from 2005 to 2013, material collected from qualitative research interviews (Kvale, 1997), participating observations, and analysis as action researchers, logbooks, films, photos, and reflection-conversations with the participants. In the observations made during the SFT workshops and performances, we have analyzed not only utterances and statements, but also body language and expressions of moods in the participants. Thus, to strengthen "artistic communication", in the first encounter between the immigrants and the drama students (Phase 4), an atmosphere of joy is sought created through working with games and exercises (Boal, 2002, p.23). Humor is central to our approach and is used consciously to create a relaxed environment when the participants explore experiences with various forms of oppression. By playing, the participants can get in touch with their past, their childhood, and the child within themselves. By getting in touch with their emotions, we hope for that they easier can open up to both joy and sorrow. One of the immigrants noted in his logbook, “I haven't played since I was little. When I am feeling sad, I almost always wish I was little again. So that I could play and know nothing about the painful..." (Songe-Møller \& Bjerkestrand, 2012, p.4). During the activities with games, we observed that Aisha and the other participants were laughing and had a good time - this is also documented on film. A joyful mood requires that we are open to ourselves and to others, joy also opens us up for what is painful (Norderhaug, 1999).

One of the exercises is about how it feels to be oppressed. The questions were: When or why do you feel oppressed? Make an image with your body of how you look when you are oppressed. What do you feel and think? Make the opposite image, when you are feeling free. What do you think and feel now? During this exercise, we observed that tears were running down Aisha's cheeks. Later, in an interview, she talked about how she suddenly remembered how she felt when she was excluded from the University in her home country ten years ago. Boal claimed that working with images like 
this could be closer to our true feelings and reveal unexpected universalities (Boal, 2002, p.xxxii, xxiii). When we analyzed Aisha's entire process in SFT, we saw that working with the games and exercises opened her up for the beginning of her awareness of the oppression that she had been subjected to in her homeland. In the reflection conversation (Phase 7), she clearly expresses through body language and words that she had a deeper form of understanding of her own self and her life history. She bends her body down when she says that she had decided to stop school, and she straightens up when she says, “...but today, I'm not going to quit school”. The aesthetic space can appear as a "free space" to experiences through senses, emotions, thoughts, fantasy, and memories (Boal, 2000, p.30). Being active physically, emotionally, and verbally could stimulate and challenge her memory, based on her experiences in her home country. Maybe she could also be aware of the role she had taken in her new life in Norway.

Aisha chose to share her story with the drama students and her classmates from the Learning Center for Immigrants, and we observed and filmed this event (Phase 5). We saw how the drama students and the other immigrants listened with empathy to her story. They agreed that they wanted to stage her story as Forum Theatre. As jokers/facilitators, we used to encourage the participants to stage stories from the multicultural society in Norway, but Aisha's group was so deeply engaged in her story that they wanted it to be explored through SFT. We then experienced an atmosphere of cohesion, loyalty, mutual responsibility, and respect in this group. The philosopher Emmanuel Levinas claimed that meeting the "face of the other" is ethically and fundamental to all human relationships (Levinas, 1995, pp.83-85). Aisha's group felt a responsibility to help to tell her story. Levinas understands responsibility for "the other" as being responsible for what is not mine. He adds that this is not about taking the responsibility for his own life from the other, but about sharing the responsibility for the other through actions (1995, p.91). Therefore, one could say, they were staging and directing Aisha's story.

The play started when Aisha met the religious police in the street and it ended at the Council of the University, where the headmaster, her teacher, and a representative from the religious leaders told her that she had to leave the University. Aisha did not want to play the main character (herself), but she wanted to stay on stage and duplicate the thoughts and feelings of the main role. Her last line in the play was, "Now my life-dream is shattered". When this Forum Play was performed at the Learning Center for Immigrants, there were about two hundred people in the audience, including immigrants and their teachers (Phase 6). Although the audience was active and eager to stop this oppression and to find a better solution to make it possible for her to return to the University, it was difficult. In the end, there was a solution from a woman in the audience, who wanted to replace the teacher at the faculty of medicine. In the improvisation, she argued that the country needs good doctors; she said, "This student is very skillful and it could be a great honor for the University to graduate such a talented student". In the theatre fiction, the headmaster discussed this matter with the 
religious leaders and they agreed to let her continue the studies after a break of three weeks. The audience shouted out to show their enthusiasm for this solution. Aisha, who was the "owner" of this story, seemed to be the most happy of them all.

Since the oppression had taken place several years before in Aisha's home country, it can be claimed that the suggested solution in this Forum play was "magic", understood as unrealistic, easy, superficial, or utopian (Engelstad, 2001). Boal claimed that one should be aware of "magic" solutions in Forum Theatre and let the audience discuss what they think is magic. The audience has the power to evaluate the proposals (Boal, 1985, pp.141-142). In this play, we argue that the "magic" solution had value, as both the audience and Aisha applauded the solution. It demonstrated the world as it should be.

\section{The transformative power of performance}

Through theatrical fiction, Aisha was able to observe a solution that would have given her the possibility to continue her studies at the University in her home country. To visualize an ideal utopian action can contribute to a sense of hope in the protagonist and reduce the powerless feeling. To feel powerless is the core of every depression. The conviction that you are powerless, and that everything is hopeless, strengthens the sense of helplessness (Norderhaug, 1999). Through SFT, there was a space of liberty where Aisha could free her memories, emotions, and imaginations, and think of her past in the present and invent the future instead of waiting for it. As Boal describes it, "The scene, the stage, becomes the rehearsal space for real life" (Boal, 1995, p.44). Furthermore, when we analyzed the filmdocumentation from Phase 6 in the SFT-process, we discovered that Aisha switched between these two roles: the role of herself as private person and the role of the protagonist on stage. When the solutions from the spect-actors is being tried out on stage and rejected by the Council of the University, she reacts spontaneously with despair in the role of the protagonist. When the final proposal succeeded in stopping the oppression, she rejoices in the role of herself on stage. She could observe herself both as a private person and as an actor. Dramaturge Janek Szatkowski (1985) calls this an aesthetic doubling, when you observe both the role and the private person acting on stage. Boal used the term "metaxis" to describe, "the state of belonging completely and simultaneously to two different, autonomous worlds: the image of reality and the reality of the image" (Boal, 1995, p.43).

In Forum Theatre, there is both the realistic acting, where the behavior on stage is based on the actual life stories, and the Brechtian acting, where the actor engages the role actively "to enter into a dialectical relationship with the role" (Schechner, 2006, p.149, 152). In SFT, there is a dialectical relationship with real life, and Aisha's reflections are linked to her real-life-situation. After the SFTperformance in the reflection conversation (Phase 7) she said that this was the first time she shared her story about being expelled from the University. She also said that she one and a half month ago had decided to stop attending the Learning Center. Then she stated loudly: "But today I am not going to 
quit school." It may seem like through the SFT experience, Aisha realized that she could influence her own life to a greater extent. The religious police in her home country had prevented her from getting an education, and now she was on the verge of stopping herself. This kind of internal oppression is what Boal called "cop in the head"(Boal, 2000, p. 52). From having been an object for others, she now wanted to be the subject in her own life. From the film-documentation, we observe that she demonstrates physically how she has been oppressed, bending her back, and bowing her head with arms dangling. With tears streaming down her face, she lifts her head, straightens her back, lifts her arms upwards and outwards, and says in a strong voice that she will continue to study. She expressed that she had obtained new hope for her own future. Hope implies that you focus on new possibilities, and is often the result of an active effort (Akerø, 1993). Here, she seemed active in a process of selfdiscovery.

To transfer this recognition from theatrical fiction to real life is challenging. The main purpose of Theatre of the Oppressed is to enable the spect-actors to "enter into the mirror of a theatrical fiction, rehearse forms of struggle and then return to reality with the images of their desires" (Engelstad, 2004:198). Boal claimed that Theatre of the Oppressed should seek not only to understand reality, "but to transform it to our own liking" (Boal, 2006, p.7). After the SFT experience (Phase 7), Aisha expressed through body and verbal language that she wanted to change her own life situation. Based on observation, film documentation, and interviews, we claim that SFT started a learning process for Aisha. The collective brainstorming in SFT was pedagogical "in the sense that we all learn together, actors and audience" (Bishop, 2012, p.124). The didactic in SFT was based on shared knowledge through theatre performance, performative didactics. In this learning process, Aisha is responsible for herself, and the audience members are responsible for themselves and the other (Levinas, 1995). 


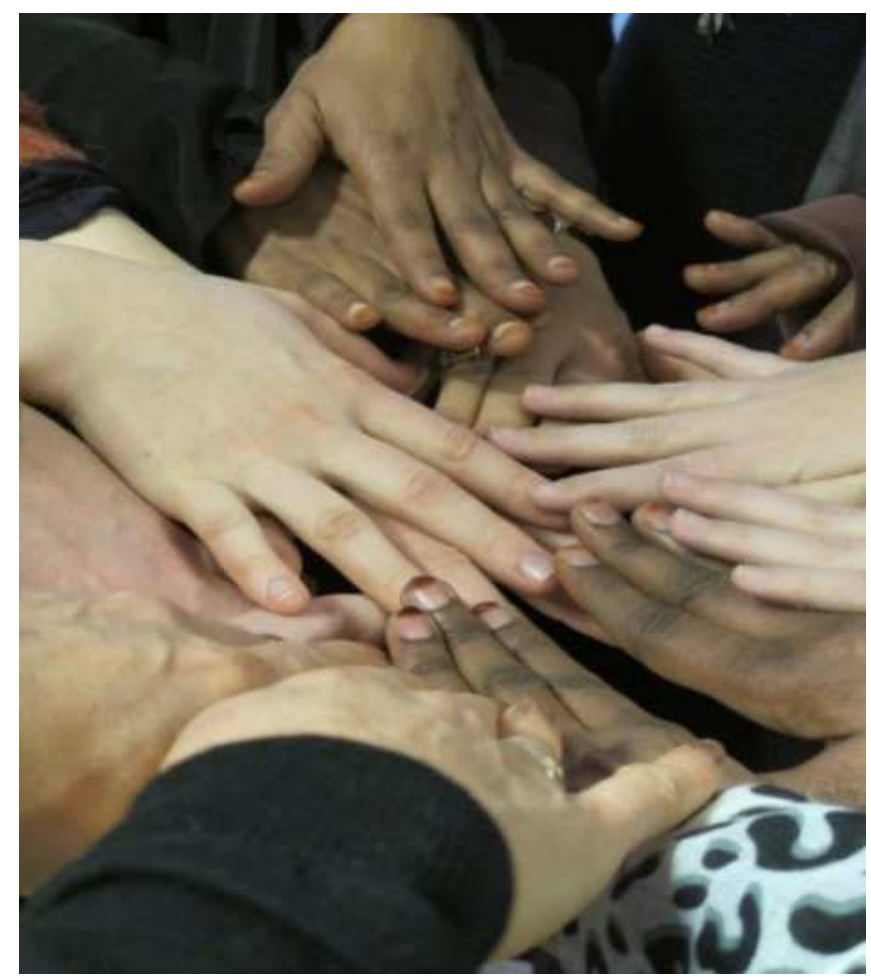

From the SFT process. Photo: Karin B. Bjerkestrand

In SFT, we observed concentration and focus both on stage and among the spectators. The spectators were listening and there was silence during Aisha's Forum play. This incited a strong sense of community spirit and solidarity. The transition from passive spectator to active participant got a collective and unifying dimension as the spect-actor took on the leading role on stage and tested out changes in order to stop oppression. Those who shouted, "Stop" and entered the stage were given the full support of the spectators, through applause and verbal cheering. The "stop" and the interaction during the $6^{\text {th }}$ phase in SFT can be characterized as a collective act of rebellion, which contributes to a strengthened community and solidarity. "The kind of knowledge that becomes solidarity, becomes a 'being with'. In that context, the future is seen, not as inexorable, but as something that is constructed by people engaged together in life" (Freire, 1998, p.72).

When Aisha, in the reflection conversation, proclaimed that she would continue to study, we interpret this as a statement of her wanting to become the subject in her own life. "Liberating action necessarily involves a moment of perception and volition" (Freire, 2003, p.51). When the participants in SFT are aware of their own situation and try to find solutions to change oppression, they can help foster community. Schechner finds seven functions of performance and claims that they function as overlapping and interacting spheres, as a network (Schechner, 2006, p.39). One of these functions of performance is to make or foster community as, "Theatre of the Oppressed empowers 'spectators' to enact, analyze, and change their situations" (Schechner, 2006, p.39). In SFT, the themes are related to the multicultural community. The main objective in SFT is to enable the participants to challenge oppression without becoming victims or oppressors and to empower them by taking on different roles 
in SFT. To become empowered means going from being a victim to becoming an active participant, from being a spectator to being a doer, from a recipient to a contributor, and from weak to strong. The intention is to strengthen the participant's ability to take on the role of the protagonist in their own lives.

Although this study does not say anything about the duration of any attitudinal and behavioral change, we are convinced that SFT functioned as an arena where the immigrants, the drama students, the actors, and the spect-actors identified, confronted, and/or explored conflicts and oppressive situations. SFT activated and involved them and opened up for discussions and reflections within an amusing and engaging setting. For Aisha in particular, SFT variously triggered joy, sorrow, hope, and perhaps, the courage to become an engineer.

\section{"II" (Venke): SFT and Performative Didactics}

Initially, SFT was presented as a part of an epistemological turn in which art departed from the role of supporter for historical and culturally-embedded values, to embrace a position from which to express the fact that the message was dependent on different contexts and relations. Where changes in theatre practice are concerned, these were characterized as a turning away from theatre as a work of art to theatre as event. The understanding of art is therefore not primarily connected to the internal work, but to different situations, participation, and interpretations. Such theatre practice can be said to be included in what I have previously described as, "the contemporary ambiguous, multi-faceted, relational, performative and context-oriented art didacticism that paves the way to a dynamic and situated topos for dissemination" (Aure, 2013, p.14). This didactic orientation endeavors to anchor art practices in the "reality narratives of the time" (Aure 2011, p.214), an aspect that can be said to be fundamental in SFT to the point of departure for dramatic processes is precisely the participants' stories from their own lives. These perspectives have things in common with the American, pragmatic performance tradition, which uses social situations in which different "negotiating positions" are adopted to debate disparate cultural values. For example, performance theorist Marvin Carlson refers to Phillip Zarrilli that describes the performance ideology in precisely these terms, saying that performance is, "not a simple reflection of some essentialized, fixed attributes of a static, monolithic culture but an arena for the constant process of negotiating experiences and meanings that constitute culture" (Carlson, 2008, p.6). Carlson also mentions the transformational potential of performance and emphasizes the achievement of specific pragmatic goals as part of performance thinking (Carlson, 2008, p.9). Based on these performative perspectives, which are also indicative/characteristic of SFT, I will characterize a type of performative didactic theatre form.

Within a performative didactic, the participant's perspective is definitive. Here, I will refer to the classic essay Deltakar og tilskodar (Participant and Spectator), which philosopher Hans 
Skjervheim published in 1957. Skjervheim's purpose for this text was mainly, as the title indicates, to problematize what happens when one makes oneself a participant as well as a spectator. He asserted that if we take a spectator's viewpoint where we see others' expressions/assertions as facts, we see the assertions as objects that can be studied objectively and from without. Skjervheim further maintains that taking such an "object" position led to a pacification and an objectification of the surrounding world. Furthermore, he also believed that this ideology acquired power and dominion over society's members, as passive spectators.

Taking Sauter's introductory description as a point of departure, I believe that "theatre as a work of art" can be framed within this epistemological tradition. To adopt a participatory position does however incur a discussion that will reflect in a critical manner, such that a participant is able to change the course of events. Consequently, "theatre as event" can be understood within the disparity of this epistemological position, in that this form of theatre involves precisely that active participation from the different actors, and change is the intention of the theatre. This participatory perspective maintains the subject position as a contributing factor in one's own and other people's meaningmaking. From this position, the individual's own role in life is made clearer and can be processed. The epistemological view on theatre as event is also connected to the foundation and practice of Applied Theatre. Although this is a diverse area, by way of summary, applied theatre theoreticians Bjørn Rasmussen and Rikke Gürgens Gjærum maintain that this theatre form deals, among other things, with theatre media form, content, and the situational context that can be a particular group, place, or a more overriding political, pedagogical, or therapeutic context (Rasmussen \& Gürgens Gjærum, 2012, p.11). Applied theatre and performance theoretician Helen Nicholson also points out the multifariousness of this form of theatre, and maintains that there is no established agreement as to the use of the concept "applied theatre", but she nevertheless maintains the following common denominators for the practice: "intervention, communication, development, empowerment and expression when working with individuals or specific communities" (Nicholson, 2005, p.3).

Augusto Boal's Theatre of The Oppressed can be seen as a radical form of Applied Theatre, as the ideal is a theatre "in which the spectators through their body and spirit become fighting actors" (Braanaas, 2008, p.168). Boal's political conviction is, as mentioned at the beginning, a theatre of liberation, which can contribute to individuals becoming conscious and to changes in society. Like Skjervheim, Boal is concerned with the spectator becoming a participant in his or her own life, and this central point is emphasized by the Boal-expert, Arne Engelstad's book title from the 1989 Theatre of the Oppressed, When the Spectator becomes Participant. Augusto Boal's Methods and Practice.

Solidarity Forum Theatre (SFT), with the seven phases presented earlier, represents a concretization of both the applied and emancipatory theatre perspective. The seven phases offer an arena where discourses can be negotiated and constructed. In joining SFT, people can tell their 
personal stories; together the stories can throw light upon differences and similarities in cultural and political narratives. These aspects have their parallel in how Irit Rogoff describes visual culture as "an arena in which cultural meaning get constituted" and "opens up an entire world of intertextuality in which images, sounds and spatial delineations are read onto and through one another, lending everaccruing layers of meaning and of subjective responses to each encounter" (Rogoff, 2006, p.24). The SFT is displayed as a multilayered event where senses, perception, and reflection are involved. For these reasons, SFT can be characterized as the interactive and sensuous activity we called performative didactics. From this standpoint, we relate to Søren Kjørup's description of Alexander Gottlieb Baumgarten's view upon aesthetics as "a kind of logic or epistemology for a specific type of knowledge, 'cognition sensitivita' in his $18^{\text {th }}$ century Latin, a kind of intuitive knowledge or what we may render as sensuous knowledge" (Kjørup, 2006, p.8).

The SFT relies seriously upon the performative aspect in the way the site and the public are not only integrated in, but also the premises for the theatre process. It is also as Mieke Bal wrote, "the unique occurrence of an act in the here-and-now" (Bal, 2002, p.176). Further, I use Bal's emphasis on the inclusion of the body, internal cultural memory, and memory-laden words as an important part of what we called the performative didactics in SFT (Bal, 2000, p.195, 209). The body's participation is particularly important where the actors do not have a well-developed common language; here the play gives substance to the words. Regarding this aspect, Norman Denzin argues that the "performed experiences are the sites where felt emotions, memory, desire, and understanding come together" (Denzin, 2003, p.13). In addition, aesthetician and cultural theorist Morten Kyndrup's description of the performative character of meaningful action as a performative doing or a performative being, not only points into the future but also back in the archives, and represents a conscious-raising reflection related to understanding Boal's preoccupation with individual oppression via "cops in the head".

The SFT-event is, I believe, special: It destabilizes conventional theatre elements, and it is also political, in an unconventional way, through the acting of personal life histories. This relates to the fact that performative strategies often destruct, or at least challenge, conventional forms of representation. As such, SFT operates in the borderland between the aesthetic and the social (Rasmussen \& Gürgens Gjærum, 2012, p.8). By understanding SFT in this way, it becomes clear that here the essentialistic epistemology and Duncan's ritual structured spaces denoting "theatre as art" are replaced by "theatre as event", as a more open and complex epistemic process. However, perhaps the most important is the epistemology signalized in how the SFT relies on trust and adds force to people's own consciousnessraising, through collaboration in theatre as event practices - a epistemological position needed for real and honest personal and intercultural communication. 


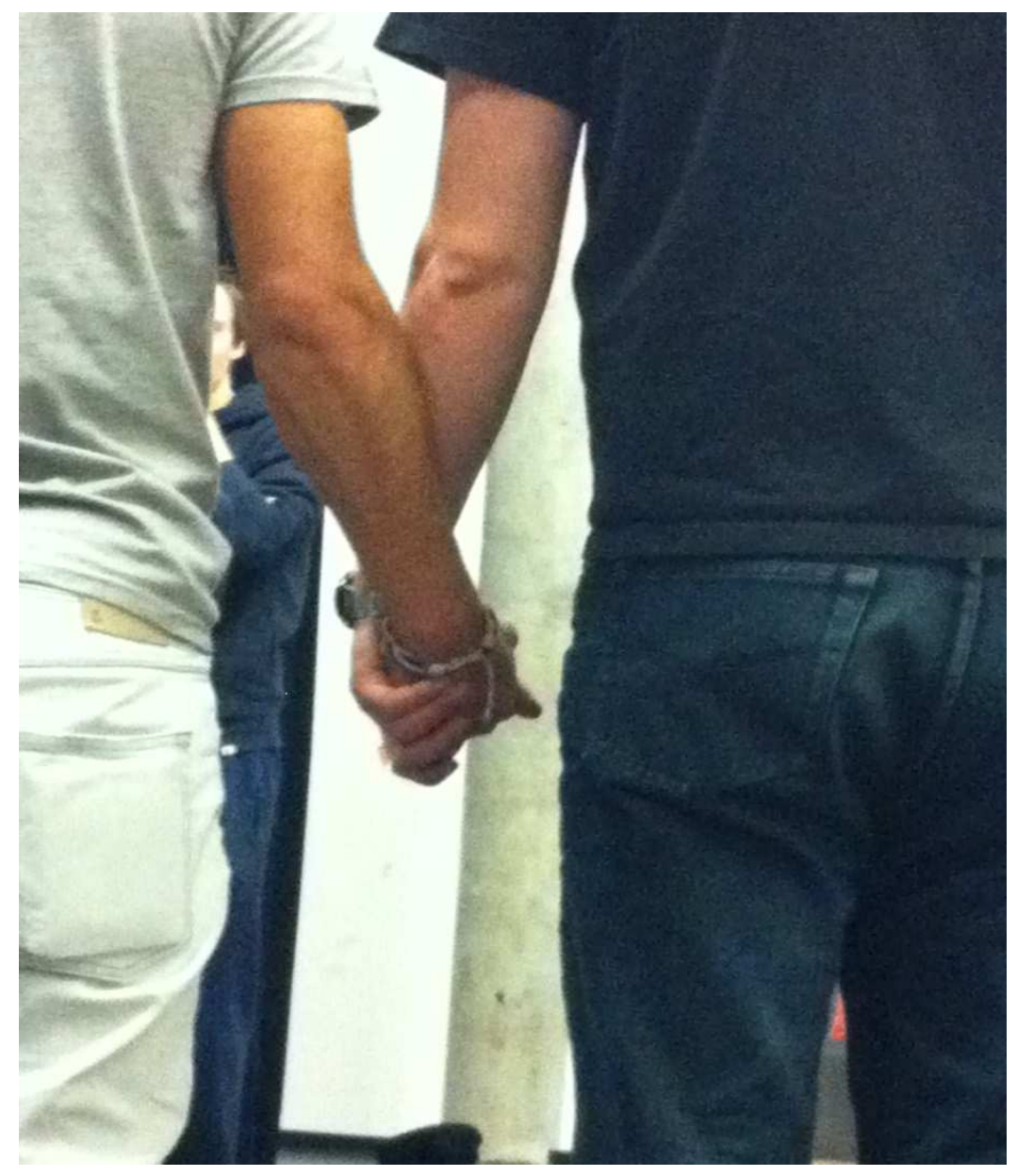

From the SFT process. Photo: Venke Aure.

\section{"We" (Anna, Karin \& Venke): Final Remarks}

The work with the SFT presented in this article is based upon a participatory action based perspective on research. This is a consistent choice, relative to the epistemological position of SFR described above. Because of its intention of improving the participant's life situation, we see a participatory action based perspective as normative. Thus the primary task of this strategy is enlightenment and consciousness-raising "or conscientization", a term popularized by Freire (1970), for a "process of self-awareness through collective self-inquiry and reflection" (Reason, 1994, p.328). Moreover, this involves, the features of the alternative knowledge and change that action science seeks to reach. Overall, participatory action based research emphasizes the social and political aspects of knowledge production (Reason, 1994, p.328). How we use Aisha's story in our research can also be described as interpretive interactionism in the way we want to "illuminate the moments of crisis that occur in a person's life", and the core of the material for the research is "the personal experience stories subjects tell one another" (Denzin, 1994, pp.510-511). Denzin stresses that these stories should be told in the language, feelings, emotions, and action of those studied, and we have tried this in part of this text (Denzin, 1994, p.511). Kyndrup's understanding of the importance of action's performative character, 
which involves the contemporary, but also a processing of the past, is addressed by Norman Denzin as an aspect of interpretive interactionism.

Progressively, the method looks forward to the conclusion of a set of acts or experiences undertaken by the subject. Regressively, the method works back in time to the historical, gender, class, race, cultural, biographical, and emotional conditions that moved the subject forward into the experience that is being studied (Denzin 2003). These methods are diverse and can be considered in light of what Clifford Geertz called "thick descriptions", a term that indicates pluralistic, interpretive, and open-ended perspectives, in addition to being connected to the possibility of making thick interpretations possible (Geertz, 1991). Overall, we see ourselves as subjects in the research process, we are fellow human beings in relation to the other actors, and we look at participatory action based research as a part of the way to find the road together. This road can be characterized through the article`s focus upon theatre as a communicative event, performative didactics and an inter-disciplinary approach. Aisha`s voice highlights what we perceive as the transformative power of performance connected to this SFT-project - her words still resonating in our ears:

This is the first time I shared my pain with others and I hope it is the last time I will cry for it. One and a half month ago I decided to stop attending the Learning Center, because I had been seriously ill, and my family situation is very difficult, but today I am not going to quit school.

\section{References}

Ackroyd, J. (Ed.). (2006). Research methodologies for drama education. Stoke on Trent, UK and Sterling, USA: Trentham Books.

Akerø, M. (1993). Håpet som ingen kunne målbinde. Om håp som skapende handling. Norsk pedagogisk tidsskrift 6 . Oslo: Universitetsforlaget.

Allvesson, M., \& Sköldberg, K. (1994). Tolkning och reflection: vetenskapfilosofi och kvalitativ metod. Lund: Studentlitteratur.

Aure, V. (2011). Kampen om blikket. En longitudinell studie der formidling av kunst til barn og unge danner utgangspunkt for kunstdidaktiske diskursanalyser. Academic Dissertation for the degree PhD. Stockholm: Stockholms universitet.

Aure, V. (2013). Didaktikk - i spennet mellom klassisk formidling og performativ praksis. InFormation - Nordic Journal of Art and Research. (2)1, 1-24.

Bal, M. (2002). Travelling concepts in the humanities : A rough guide. Toronto: University of Toronto Press.

Berulfsen, B., \& Gundersen, D. (1989/1993). Fremmedordbok. Kunnskapsforlagets blå ordbøker. Oslo: Aschehoug - Gyldendal.

Bishop, C. (2005). Installation art: A critical history. London: Tate. 
Aure, Bjerkestrand and Songe-Møller: Emancipatory Theatre and Performance Didactics

Boal, A. (1996/2000). Lystens regnbue. Boals metode for teater og terapi. Oversat av Niels Damkjær. Gråsten: DRAMA.

Boal, A. (1992/2005). Games for actors and non-actors (2nd ed.). Oxon: Routledge.

Boal, A. (2006). The aesthetics of the oppressed. London and New York: Routledge.

Boal, A. (1985). Stop! Det er magisk! Oversat fra fransk af Inger Holm. Gråsten: Teaterforlaget DRAMA.

Braanaas, N. (2008). Dramapedagogisk historie og teori. Trondheim: Tapir akademisk forlag.

Carlson, M. (2008). Perspectives on performance: Germany and America. I: Fisher-Lichte, E. The transformative power of performance. A new aesthetics. London and New York: Routledge.

Carr, W., \& Kemmis, S. (1986). Becoming critical. Education, knowledge and action research. London: Falmer Press.

Crafoord, C. (2005). Människan är en berättelse. Stockholm: Natur och Kultur.

Denzin, Norman. K. (2003). Performance ethnography. Critical pedagogy and the politics of culture. Thousand Oaks: Sage Publications.

Dilthey, W. (1894/1977). Descriptive psychology and historical understanding. The Hague: Martinus Nijhoff.

Duncan, C. (1995). Civilizing Rituals: Inside Public Art Museums. London: Routledge.

Engelstad, A. (1989/2001). De undertryktes teater. Når tilskueren blir deltaker. Augusto Boals metoder og praksis. Oslo: Cappelen Akademisk Forlag.

Engelstad, A. (2004). Poetikk og politick. Augusto Boal og De undertryktes teater. Åbo: Åbos Akademis förlag.

Engelstad, A. (2009). Minneord om Augusto Boal i Drama, Nordisk dramapedagogisk tidsskrift nr. 3. Oslo: Landslaget Drama i Skolen (LDS).

Fisher-Lichte, E. (2008). The transformative power of performance. A new aesthetics. London and New York: Routledge.

Freire, P. (1968/2003). Pedagogy of the oppressed. New York: Continuum.

Freire, P. (1998). Pedagogy of freedom. New York: Rowman and Littlefield.

Geertz, C. (1991). Tjock beskrivning. För en tolkande kulturteori. Häften för kritiska studier. 24 (3).

Kjørup, S. (2006). Another way of knowing. Baumgarten, aesthetics, and the concept of sensuous cognition. I: Sensuous knowledge. Focus on artistic research and development, no 1. Bergen: Kunsthøgskolen I Bergen.

Korhonen, K., \& Räsänen, P. (Ed.). (2010). The event of encounter in art and philosophy. Helsinki: Gaudeamus, Helsinki University Press.

Kosuth, J. (1990). Skrifter 1966-1990. København: Det kgl. Danske Kunstakademi.

Kyndrup, M. (2006). Performativitet, æstetik, udsigelse: Lille note om det performatives ærsteik. Peripeti (6). 
Aure, Bjerkestrand and Songe-Møller: Emancipatory Theatre and Performance Didactics

Levinas, E. (1982/1995). Etik og Uendelighed. Samtaler med Philippe Nemo. Gylling: Hans Reitzels Forlag.

Neelands, J. (2009). Acting together: Ensemble as a democratic process in art and life. Research in drama education: The Journal of Applied Theatre and Performance, (14)2, 173-189. http://dx.doi.org/10.1080/13569780902868713

Nicholson, H. (2005). Applied drama. The gift of theatre. New York: Palgrave Macmillan.

Rasmussen, R., \& Gürgens Gjærum, R. (red.). (2012). Vitenskapsteori og kunnskapssyn i anvendt drama-/teaterforskning. In: Forestilling, framføring og forskning: metodologi $i$ anvendt teaterforskning (p. 7-20). Trondhjem: Akademika Forlag.

Rogoff, I. (2006). What is visual culture studies? London: Routledge.

Sauter, W. (2000). The theatrical event: Dynamics of performance and perception. Iowa City: University of Iowa Press.

Schechner, R. (2006). Performance studies an introduction. London and New York: Routledge.

Skjervheim, H. (1957). Deltakar og tilskodar. Oslo: Instituttet for sosiologi, Universitetet I Oslo.

Songe-Møller, A. S., \& Bjerkestrand, K. B. (2012). Empowerment of citizens in a multicultural society. Journal of Intercultural Communication. ISSN 1404-1634.

Szatkowski, J. (1985). “Når kunst kan brukes” i Dramapedagogikk II I Nordisk perspektiv. Teaterforlaget Drama.

Tiller, T. (red.). (2004). Aksjonsforskning i skole og utdanning. Kristiansand: Høyskoleforlaget.

Valberg, T. (2013). Perikhoresis' emansipatoriske impuls eller: Bert Brecht er død - leve Berth Brecht! InFormation - Nordic Journal of Art and Research. (2)1, 54-69.

\section{Online resources}

http://www.griffith.edu.au/_data/assets/pdf_file/0010/114958/07-GArgens-GjArum-and-Ramsd.pdf

http://www.immi.se/intercultural/nr30.html

http://www.theatreoftheoppressed.org/en/index.php?useFlash=1 